\title{
VOCATIONAL-TECHNICAL EDUCATION IN NIGERIA: A REVIEW
}

\author{
U. N. IKPE \\ (Received 17 August 2009; Revision Accepted 12, January 2010)
}

\begin{abstract}
Vocational-technical education (VTE) is defined as that aspect of education which leads to the acquisition of practical and applied skills as well as basic scientific knowledge. The major focus of this paper was to examine the trend in VTE, its development from the pre-colonial, colonial and post independence eras. This paper discusses different levels where VTE is offered. The problems were identified and recommendations for solutions were suggested.

\section{INTRODUCTION}

\section{Western Education}

The introduction of Western education into Nigeria dates back to the year 1842, when on the invitation of some Yoruba immigrants from Sierra Leone who had settled in Badagry some 50 kilometres west of Lagos, the Wesleyan Methodist Missionary Society sent the Reverend Thomas Birch Freeman from Cape Coast where he had been the superintendent of the Methodist Mission. By 1860 , four missionary societies in Nigeria - the Western Methodist, the Church Missionary Society (CMS), the Baptist and the Roman Catholic Mission (RCM) - had established stations. Others that followed include the Qua Iboe Church of Northern Ireland in 1887 and the Primitive Methodist Society in 1872. These missionary bodies founded schools whenever and wherever they established missions (Ukeje \& Aisiku, 1982; Nduka, 1961).

\section{Vocational-Technical Education}

According to Roberts (1965) vocational education could be defined as that aspect of education designed to develop skills, attitudes, work habits and aspirations encompassing knowledge and information needed by workers to enter and make progress in employment on a useful and productive basis. He further described vocational education as an integral part of total education programme contributing towards the development of good citizens by developing their

physical, social, civic, cultural and economic competencies. As contained in the Encyclopedia Americana (International Edition) (1991), the aim of vocational education is to prepare young people and adults for useful occupations, particularly for skilled trades and semiprofessional careers. It also may update the knowledge and skills of workers in occupations of this kind. Similarly, the United Nations Educational Scientific and Cultural Organizations (UNESCO) Document (1974) stated that technical and vocational education is used as a comprehensive term referring to those aspects of educational process involving in addition to general education, the study of technologies and related sciences and the acquisition of practical skills, attitudes, understanding and knowledge relating to occupations in various sectors of economic and social life. Technical and vocational education is a phase of general education which is a means of preparing for an occupational field or an aspect of continuing education. It offers instruction in a wide range of trades and occupations to enable the receiver fit into the world of work.

\section{Aims of Vocational-Technical Education}

The Nigeria National Policy on Education (2004) sets the aims of vocational-technical education as follows:

(a) the provision of trained manpower in applied science, technology and commerce particularly at sub-professional grades;
\end{abstract}

U. N. Ikpe, Department of Vocational Education, Faculty of Education University of Calabar, Calabar, Nigeria 
(b) the provision of technical knowledge and vocational skills necessary for agricultural, industrial, commercial and economic development;

(c) the provision of people who can apply scientific knowledge to the improvement and solution of environmental problems for the convenience of man;

(d) the giving of training and imparting the necessary skills leading to the production of craftsmen, technicians and other skilled personnel who will be enterprising and self-reliant; and

(e) the enabling of young men and women to have an intelligent understanding of the increasing complexity of technology.

\section{Vocational-Technical Education in Pre- colonial Nigeria}

Fafunwa (1974) maintained that education in the traditional African setting had the concept of functionalism as the main guiding principle. The acquisition of specific vocational training and the development of a healthy attitude towards honest labour was the hallmark of education. On pre-colonial vocational education, Fafunwa went further to explain that in the traditional Nigerian society prior to the advent of western education vocational training was categorized into (a) vocational-agricultural education and (b) trades and crafts.

Vocational-agricultural education - Nigerians engaged in practical farming, fishing and livestock.

Trades and crafts - Trades and crafts cover weaving, smithing, building, carpentry, leatherworking, dyeing, soap making, "osusu-collecting" (banking) catering, trading in both agricultural and manufactured goods. Skills and trades "owned" by any family or tribe were highly valued and guarded up till present day. For example the following ethnic groups specialized in the following trades (Ikpe, 2000)

\begin{tabular}{ll}
$\begin{array}{l}\text { Tribe } \\
\text { Edo }\end{array}$ & \multicolumn{1}{c}{ Trade } \\
Sculpture/Carving \\
Kano & Leather working/Dyeing \\
Yorubas & Blacksmithing \\
(Ibadan)/Birom tribe & \\
Bida & Pottery-making \\
Akwete & $\begin{array}{l}\text { Textile weaving } \\
\text { Akwa lbom }\end{array}$ \\
Raffia works
\end{tabular}

Apprenticeship training

Vocational training in the pre-colonial society (Nigeria) was conducted largely on the apprenticeship system. By this method, the young persons were not directly trained by their parents but by relatives, master craftsmen or friends of their families in a particular field to ensure concentration and discipline. During the period of apprenticeship the trainees live and learn the trade or skill with the master who would feed and cater for them while the apprentices would assist the masters on household chores and farm-work mostly those in the rural areas. Those in urban centres undergoing technical training live on their own but attain the training in their master's workshops. The apprenticeship system produces semi-skilled artisans and craftsmen in auto mechanics, electrical installation, radio and TV repairs, carpentry, tailoring and building construction.

\section{Vocational-Technical Education in Colonial Nigeria}

In its modest form, technical and industrial training were conducted in workshops and centres attached to the government, commercial and industrial establishments. Vocational subjects were not offered in the then existing secondary schools curricula. The school curriculum was devoted to the teaching of three "Rs" that is, reading; writing and arithmetics for the production of catechists and interpreters for purpose of evangelism and clerical hands for colonial administration and mercantile establishments. Major departments that organized rudimentary vocational and technical training were Public works, Post and Telegraphs, Marine and Agriculture. Other colonial establishments that had training units attached to them were Nigerian Railway Corporation (NRC), United African Company (UAC), John Holt and United Trading Company (UTC) (Nduka, 1975, Osuala, 1998 \& Inwang, 2000).

According to Okoro (1994) the only meaningful effort by the colonial administration towards technical education was the 1946. Ten year for development and welfare led to the establishment of the Yaba Technical Institute in 1947 and some Trade centres around the country. By 1952, three technical institutions were established at Yaba, Enugu and Kaduna. Seven Trade centres and eighteen handicraft centres were also established in Nigeria. 


\section{Nigerian College of Arts, Science and Technology}

Nigerian government in 1949 set up a commission to conduct a feasibility survey of the polytechnic idea in terms of Nigerian needs. The 2-man commission - F.J. Harlow, Principal of Chelsea Polytechnic London and W.H. Thorp, Deputy Director of Education (Nigeria), made a strong case for technical education in order to meet the requirements of industry, commerce and society as well as to adjust to the changing needs of the environment. Thus the commission recommended the setting up of a Nigerian College of Arts, Science and Technology with branches in each of the three regions. The college was to engage in professional and subprofessional training in the following programmes: (a) Teachers training for trade schools and junior technical institutes; (b) building, civil engineering, surveying, mechanical and electrical engineering; mining, geology and telecommunications; (c) agriculture, forestry and veterinary sciences (d) medical auxiliary services; and (e) extra-mural or adult education. Fafunwa (1982) concluded that a Bill for the founding of the college was introduced into the Nigerian legislature in April, 1952.

\section{Survey School, Oyo/Yaba Higher College}

According to Fafunwa (1971), owing to the acute shortage of trained European surveyors in the colonial territory - the survey school was opened in Lagos in 1908. The institution was relocated to the present site at Oyo in 1934. In the same spirit, the Yaba Higher College was established in 1930 first as a medical school; and later courses in engineering; business and technology were added around 1936.

\section{Trade School}

The trade school offer pre-vocational course to students who have completed a full primary school course. The course lasts for three years and leads to the award of National Technical Certificate (NTC) conducted by National Business and Technical Examination Board (NABTEB). The technical subjects most commonly offered are:
(a) Technical Drawing
(b) Mechanical Technology
(c) Electrical Technology
(d) Building Technology

Students may also be required to take nontechnical subjects such as;

(i) English Language

(ii) History

(iii) Geography (iv) General Science

(v) Home Economics

(vi) Mathematics

Graduates of trade schools are encouraged to gain admission into Technical Colleges for full vocational training or obtain work in industry as artisans.

\section{Technical College}

Technical colleges admit students who have completed the trade schools course and offer a full vocational course which is of three years duration. Students could be transferred from secondary technical schools to technical colleges. At the end of 5-year course, students take Advanced National Technical Certificate (ANTC) examination which replaces the City and Guilds of London Institute.

Technical colleges in Nigeria train craftsmen in auto mechanics, plumbing, carpentry and joinery, cabinet making, painting and decorating, welding, electrical installation, radio and TV repairs and building construction. Graduates of Technical Colleges usually obtain employment in industry or establish their own business (Okoro, 1991).

\section{Commercial Secondary School}

Commercial secondary schools are high schools which offer vocational-business and nonbusiness subjects. At the end of the fifth or sixth year students take General Certificate of Education (GCE) or Senior School Certificate Examination (SSCE) in both business and academic subjects. Subjects offered in Commercial Schools are:
(a) Principles of Accounting/Bookkeeping
(b) Commerce
(c) Economics
(d) Typewriting/Computer
(e) Shorthand
(f) Office practice
(g) Business Mathematics

Non-commercial subjects offered in commercial secondary schools are:
1) English Language
2) Literature in English
3) History
4) Government
5) Geography
6) Mathematics

\section{Junior/Senior Secondary School (3-3 system)}

In the new education system often referred to as the 6-3-3-4 system, the secondary school programme is of six years duration divided 
into 3-year junior secondary school (JSS) programme and a 3-year senior secondary school (SSS) programme. The new system abolishes the conventional grammar school system. The main characteristic of new policy on education is the greater importance attached to pre-vocational and vocational education. All students in the junior secondary schools are to take two pre-vocational courses selected from Agriculture, Business Studies, Home Economics and Introductory Technology. Students in the senior secondary schools are expected to offer a vocational subject and take it in their final examination. The vocational subjects to be chosen from the approved list of subjects include:

$\begin{array}{ll}> & \text { Commerce } \\ > & \text { Economics } \\ > & \text { Bookkeeping } \\ > & \text { Typewriting } \\ > & \text { Shorthand } \\ > & \text { Agricultural Science } \\ > & \text { Home Economics } \\ > & \text { Elal Work } \\ > & \text { Technical Drawing } \\ > & \text { Woodwork } \\ > & \text { Auto-mechanic }\end{array}$

The major aim of the reform is to make
senior secondary school leavers easily employable, and this the policy hopes it will achieve by making every senior school student to take at least one vocational subject before graduation.

\section{College of Education (Technical)}

Technical teacher education appears to have had a late start in the Nigeria educational system. There was no formal local technical teacher programme in Nigeria before 1962. Up to this time, the training of technical-vocational teachers was wholly undertaken in the United Kingdom (UK) in such institutions as the Huddersfield College of Education (Technical) and Bolton College of Education (Technical). Other institutions within UK that engaged in the training of technical instructors for vocationalbusiness subjects for Nigerian Civil Service were Pitman College and Grannett College in London (Ikpe, 2000). Training was also undertaken at the International centre for Advanced Technical and Vocational Training in Turin, Italy. The centre was established in 1965 by the International Labour Organization (ILO), (Inwang, 2000).
The Federal Government's pioneering effort to establish permanent training institutions for the production of Vocational-Technical teachers did not formally commence until 1968 when the National Technical Teacher College (NTTC) was started in Lagos. The College came into existence with the grant received from UNESCO/UNDP/World Bank. The college now renamed - Federal College of Education (Technical) was basically to train NCE (Business), NCE (Technical) and Technical Teachers Certificate (TTC) teachers. A wide range of vocational-technical teaching subjects were offered in addition to professional education courses. The students were drawn from all the states of the Federal Republic of Nigeria.

As at present, the colleges which have increased in number are as follows:

$>\quad$ Federal College of Education (Technical) Akoka-Yaba, Lagos State.

$>\quad$ Federal College of Education (Technical)

Gombe, Gombe State.

$>\quad$ Federal College of Education (Technical)

Asaba, Delta State

$>\quad$ Federal College of Education (Technical)

Bichi, Kano State.

$>$ Federal College of Education (Technical)Omoku, Rivers State.

$>\quad$ Federal College of Education (Technical) Umunze, Anambra State.

$>\quad$ Federal College of Education (Technical)

Potiskum, Yobe State.

$>\quad$ Federal College of Education (Technical) (female), Gusau, Zamfara State.

$>\quad$ Federal College of Education (Technical) Obudu, Cross River State.

To complement the efforts of the above listed colleges, both Federal and State Conventional Colleges of Education and the Polytechnics are encouraged to offer business and technical teachers education at least up to the level of Nigeria Certificate of Education (NCE).

\section{Polytechnic}

The greatest activity in Vocational Technical education was the development of Polytechnics in Nigeria. Polytechnic is a tertiary vocational institution. The institutions offer a 2year National Diploma (ND) and also a 2-year Higher National Diploma (HND). A holder of national diploma must undergo one year students industrial work experience scheme (SIWES) to be eligible for admission to HND programme. A wide range of courses are offered in the Polytechnic (see Appendix2). 
University

The Federal Government of Nigeria had since the introduction of National Policy on Education (1981) placed emphasis on vocational technical education. This emphasis led to the establishment of Technical Colleges, Colleges of Education (Technical), several Polytechnics and Universities in various parts of the country and the introduction of programmes of technical education. All these programmes require well trained instructors and lecturers with postgraduate qualifications.

Currently, many Nigerian universities are offering bachelors, masters and doctorate degrees in various aspects of vocational-technical education. For example, the University of Nigeria, Nsukka which commenced classes on the $17^{\text {th }}$ October, 1960 had in its chartering documents not only academic and cultural excellence but also scientific and vocational excellence.

The following programmes of instructions are some aspects of vocational-technical education offered at graduate levels in Nigerian universities:

(A) Vocational-Agricultural Education

$\checkmark$ Farmer Education and productivity

$\checkmark$ Agricultural Resources Management Education

$\checkmark$ Agricultural Production Education

$\checkmark$ Soil Education

(B) Vocational-Business Education

$\checkmark$ Accounting Education

$\checkmark$ Marketing and Distribution Education

$\checkmark$ Office Education

(C) Vocational Home-Economic Education

$\checkmark$ Clothing and Textile

$\checkmark$ Food and Nutrition

$\checkmark$ Home Management

$\checkmark$ Child Development, care and Family

(D) Industrial-Technical Education

$\checkmark$ Building Construction

$\checkmark$ Electrical/Electronics

$\checkmark$ Mechanical Technology

Technical Teachers Training Programme (TTTP)

In 1980, the Federal Government of Nigeria and United State of America (USA) signed a bilateral agreement for Technical Teachers Training Programme (TTTP) abroad. By this arrangement, the training programme was designed for vocational-technical teachers to undertake in-service training courses at various levels in American accredited colleges and universities for higher qualifications in all aspects of vocational-technical education. The programme was for holders of Nigeria Certificate in Education (NCE), Higher National Diploma (HND) and Bachelors degree in relevant vocational-technical courses. About 500 technical instructors were trained yearly.

The Overseas TTTP has been discontinued and currently selected tertiary institutions are participating in the training programme. The participating institutions include University of Nigeria, Nsukka; Ahmadu Bello University, Zaria; University of Uyo; Federal Universities of Technology Minna and Yola. Others are Yaba College of Technology and Kaduna Polytechnic (Olaitan, 1996 and Ikpe, 2000).

\section{Accreditation}

In Nigeria, accreditation of vocationaltechnical education programmes is carried out by the following statutory agencies:

\section{(a) National Commission for Colleges of} Education (NCCE)

The agency that is responsible for the accreditation of programmes offered in College of Education (Technical) is the National Commission for Colleges of Education along with National Board for Technical Education (NBTE). Nigerian Certificate in Education (Business and Technical) programme is often subjected to detailed accreditation by the Commission assisted by the Board.

\section{(b) National Board for Technical Education (NBTE) \\ NBTE is vested with the responsibility for} accreditation of programmes in Polytechnics, institutions. NBTE is one of the greatest developments that have occurred in technical education. The Board has a status parallel to that of the National Universities Commission and the National Commission for Colleges of Education, (see Appendix 1 for the Board's detailed functions).

\section{National Universities Commission (NUC)}

The legal basis for the accreditation of programmes in the universities is derived from Decree N0.16 of 1985. Section 10 of the Decree as amended and incorporated in Section 4 (A) of the National Universities Commission: 
Amendment Decree N0.49 of 1988 empowered the commission:

"to lay down minimum standards for all universities in the Federation and to accredit their degrees and other academic awards..."

The following items are often demanded by the accreditation panel for academic (degree) programme: (a) philosophy and objectives of the programme to be accredited, (b) curriculum (c) teaching staff quantity and quality, (d) students admission, retention and graduation (e) standards of degree examination (f) financial support and $(\mathrm{g})$ physical facilities.

\section{Certification}

Prior to post-independence Nigeria, foreign based examination bodies were responsible for examining and awarding certificates to products of vocational technical education. These examination bodies were:

(a) City and Guide (C\&G) of London

(b) Royal Society of Arts and Commerce

(c) Pitman Examination Institute

(d) Chartered Institution of Secretaries (CIS)

At present, the Federal Government has

set up National Business and Technical Examination Board (NABTEB) to examine and award National Business Certificate (NBC) and National Technical Certificate (NTC) in ordinary and advanced level for products of technical colleges. For College of Education (Technical), Polytechnic and University, these institutions award Certificates, Diplomas and Degrees in various aspects of vocational-technical education (lkpe, 2000).

\section{Problems of Vocational-Technical Education in Nigeria}

Some of the problems facing the growth of vocational-technical education in Nigeria could be summarized as follows:

1. Acute shortage of high caliber instructional personnel at all levels of vocationaltechnical education in Nigeria.

2. Inadequate funding of vocational education programmes at all levels.

3. Lack of modern training facilities and equipment.

4. Inherited negative colonial mentality on vocational-technical education by Nigerian educational administrators.

5. Inadequate post-graduate training institutions for the training of instructors and lecturers.

6. Lack of professional books and journals on vocational-technical education.
7. Poor public attitude to technical education, insisting that vocational-technical education is for drop-outs and children from poor socio-economic background.

8. Appointment of non-professional vocationaltechnical educators to both teaching and administrative positions to administer vocational education programme.

9. Haphazard implementation of pre-vocational and vocational education in the national policy on education.

10. Corruption on the part of officials who administer vocational-technical education.

11. Lack of awareness on the part of government officials on the importance of vocationaltechnical education on the economy of the nation.

12. High cost of instructional equipment and inadequate power supply to training workshops and other facilities that require electricity.

13. Dependency on foreign industrial nations for technical assistance.

14. Lack of motivation and poor conditions of service for technical instructors who should implement policy on technical-vocational education

Measures to promote vocational-technical education in Nigeria

(a) Adequate budgetary allocation should be made for vocational-technical education due to the capital intensive nature of the programme.

(b) Federal Government of Nigeria should set up a standing conference of technical education to facilitate cooperation between training institution and the industrial firms.

(c) The expansion of training facilities for both trainers and trainees

(d) The curriculum of vocational-technical education should be broadened and industries should be encouraged to accept trainees on industrial attachment.

(e) State and local governments should establish multi-purpose vocational centres for artisan training.

(f) National Directorate of Employment (NDE) programmes should be expanded especially in the rural areas.

(g) Government should intensify effort to provide electricity to technical schools to make their workshops functional. 
(h) Vocational-technical education should be tuition free for the students.

(i) The government should procure relevant textbooks and library materials.

(j) Financial assistance should be granted to vocational-technical education graduates who want to set up industrial enterprises.

(k) Better conditions of service should be put in place for technical instructors.

(I) Female should be encouraged to enroll in vocational-technical education.

\section{CONCLUSION}

The importance of vocational and technical education has been recognized by the present Federal and State Governments in Nigeria. Vocational-technical education has achieved economic aims because investment in vocational programmes provides individuals with employable skills and provides the economy with productive citizens.

Vocational-technical education is important because individuals who have saleable skills become useful citizens in their communities rather then parasites. The objectives of vocational-technical education at Trade centre, Technical colleges, College of Education (Technical), Polytechnics and Universities is to train individual and raise capacities and technical skills to meet industrial needs for Nigeria's industrial sector. Vocational-technical education has a major role to play in the implementation of the policy of indigenization of Nigeria economy. This has witnessed an increase in number of technical institutions since Nigeria obtained political independence in October 1960.

\section{REFERENCES}

Encyclopedia Americana (International Edition), 1991. Denbury, Connecticut Groiler Inc.

Fafunwa, A.B., 1974. History of education in Nigeria, London, George Allen \& Unwin Limited.

Federal Republic of Nigeria, 2004. National Policy on Education, NERC, Lagos.

Federal Republic of Nigeria: The 6-3-3-4 System of Education at a glance, Lagos, Federal Ministry of Education.
Ikpe, U.N., 1998. An Overview of the development of Business teacher education in Nigeria. Journal of Education Foundations 2, (1): 92-104.

Ikpe, U.N., 2000. An introduction to VocationalBusiness Education in Nigeria, Calabar: Ephraim Publishing Company

Inwang, I. I., 2000. Technical education and training in Nigeria: Development from 1900 to the present. Calabar: HILEMO Associates.

Nduka, O., 1961. Western education and the Nigerian cultural background. Ibadan: Oxford University Press.

Okoro, C.M., 1994. Principles and methods in Vocational education. Enugu: ABIC Publishers.

Olaitan, S.O., 1996. Vocational and technical education in Nigeria (Issues and Analysis).

Osuala, E.C., 1996. Foundations of vocational Education $\left(4^{\text {th }}\right.$ edu), Onitsha: Cape Publisher International Limited.

Roberts, R.W., 1965. Vocational and practical arts education-history, development and principles $\left(2^{\text {nd }}\right.$ edu)., New York: Harper and Row Publisher.

Ukeje, O. and Aisiku, J.U., 1982. Education in Nigeria. In Babs Fafunwa \& Aisika, J.U (eds) Education in African: A comparative survey. London, George Allen \& Unwin.

UNESCO's, 1974. Recommendations concerning technical and vocational education, General conference - 17 October - 29 November, 1974.

University of Nigeria Calendar, School of postgraduate studies 2003-2005.

National board for technical education (NBTE) Decree N09 of 1977.

National Commission for colleges of Education (NCCE), 1990. 